\title{
Evaluation in vitro of the infection times of engorged females of Rhipicephalus (Boophilus) microplus by the entomopathogenic nematode Steinernema glaseri CCA strain
}

\author{
Avaliação in vitro dos tempos de infecção de fêmeas ingurgitadas de Rhipicephalus (Boophilus) \\ microplus pelo nematoide entomopatogênico Steinernema glaseri estirpe CCA
}

\author{
Leandro Barbiéri de CarvalhoI John FurlongII Márcia Cristina de Azevedo PrataII \\ Éder Sebastião dos Reis ${ }^{\text {II }}$ Elder Simões de Paula Batista ${ }^{\text {III }}$ Aline Pasqualini Faza ${ }^{\text {III }}$ \\ Rômulo Cerqueira Leite ${ }^{\mathrm{IV}}$
}

\begin{abstract}
Studies have shown that ticks are susceptible to infection by entomopathogenic nematodes. These studies indicate different susceptibilities of ticks to infection by these fungi, depending on the tick species, development phase, entomopathogenic nematodes species and strains and the time the ticks are exposed to them. Usually this period ranges from 24 to 72 hours. The aim of this study was to evaluate the infection times in vitro of engorged Rhipicephalus (Boophilus) microplus females by the entomopathogenic nematodes Steinernema glaseri CCA strain, by analysis of the ticks' biological parameters. The results show that a 2-hour exposure time was sufficient for the engorged $\boldsymbol{R}$. microplus females to be infected by S. glaseri CCA, but that a minimum exposure time of 24 hours was necessary to generate treatment efficacy above $90 \%$.
\end{abstract}

Key words: entomopathogenic nematode, Rhipicephalus (Boophilus) microplus, tick, Steinernema glaseri, biologic control.

RESUMO

Os carrapatos são susceptíveis à infecção por nematoides entomopatogênicos. Essa susceptibilidade diverge quanto às espécies de carrapato estudadas, à fase evolutiva, às espécies e estirpes dos nematoides e ao tempo ao qual os carrapatos ficam expostos a estes. O presente trabalho teve como objetivo avaliar os tempos de infecção in vitro de fêmeas ingurgitadas de Rhipicephalus (Boophilus) microplus pelo nematoide entomopatogênico Steinernema glaseri estirpe CCA, pela análise dos parâmetros biológicos do carrapato. Os resultados obtidos demonstraram que um período de duas horas de exposição foi suficiente para que fêmeas ingurgitadas de $\boldsymbol{R}$. microplus fossem infectadas por S. glaseri CCA e que um período de exposição mínimo de 24 h foi necessário para que houvesse infecção de fêmeas ingurgitadas de $\boldsymbol{R}$. microplus por S. glaseri estirpe CCA, capaz de gerar, in vitro, eficácia no tratamento superior a $90 \%$

Palavras-chave: nematoide entomopatogênico, Rhipicephalus (Boophilus) microplus, carrapato, Steinernema glaseri, controle biológico.

\section{INTRODUCTION}

Rhipicephalus (Boophilus) microplus (Canestrini 1887) Murrell and Barker is an important cattle parasite due to the considerable economic losses caused to herds (GRISI et al., 2002). Current control measures basically consist of applying chemical acaricides. However, the incorrect use of these substances has led to the appearance of tick populations resistant to the various chemical groups used (KUNZ \& KEMP, 1994). Moreover, there is increasing social concern over environmental preservation and human health, which often comes into conflict with the need to assure agricultural productivity. Therefore, it is important to find efficient methods that are less aggressive to the environment and human health to control pests, such as ticks, that afflict animal herds.

\footnotetext{
ICoordenação Geral de Apoio Laboratorial, Secretaria de Defesa Agropecuária, Ministério da Agricultura, Pecuária e Abastecimento (MAPA), 70043-900, Brasília, DF, Brasil. E-mail: carvalholb@gmail.com. Autor para correspondência. "Embrapa Gado de Leite, Juiz de Fora, MG, Brasil.

IIIniversidade Federal de Juiz de Fora (UFJF), Juiz de Fora, MG, Brasil.

${ }^{\mathrm{I}}$ Universidade Federal de Minas Gerais (UFMG), Belo Horizonte, MG, Brasil.
} 
The use of entomopathogenic nematodes (EPNs) as biological control agents has been attracting great interest because these nematodes infect and kill many families and orders of arthropods, and they can be cheaply produced in their infective juvenile form in host insects or by artificial means (DOLINSKI, 2006).

Many studies have shown that ticks are susceptible to infection by EPNs. Thirteen ixodid tick species and two argasid species were shown to be susceptible to nematodes, with adults apparently being more susceptible (SAMISH, 2000). Engorged Rhipicephalus (Boophilus) annulatus females were susceptible to infections by entomopathogenic nematodes (SAMISH \& GLAZER, 1992). Steinernema glaseri and Steinernema carpocapsae were pathogenic to engorged Ixodes scapularis females (ZHIOUA et al., 1995). KOCAN et al. (1998a) observed that Dermacentor variabilis, Rhipicephalus sanguineus, Amblyomma maculatum and Amblyomma cajennense were susceptible to infection by Steinernema feltiae and Steinernema riobravus.

In Brazil, VASCONCELOS et al. (2004) studied two species of EPNs, $\boldsymbol{S}$. glaseri Santa Rosa strain and Heterorhabditis bacteriophora CCA strain, for control of $\boldsymbol{R}$. microplus, and evaluated the female mortality, egg mass weight, preoviposition period, larval hatching percentage and reproductive and nutritional efficiency indices, using seven concentrations of the EPNs. They found that the nematodes were efficient in the in vitro control of $\boldsymbol{R}$. microplus, with high level of mortality and low egg mass weight. REIS-MENINI et al. (2008) evaluated the association between the EPN S. glaseri Santa Rosa strain and an organophosphate acaricide, at different dilutions, for the control engorged $\boldsymbol{R}$. microplus females. The results indicated compatibility between $\boldsymbol{S}$. glaseri and the acaricide to control $\boldsymbol{R}$. microplus and showed a possible synergetic action between these agents.

The cited studies indicate different results for ticks susceptibility to the infection by EPNs depending on the tick species studied, ticks' development stage, species and strains of EPNs and time that ticks were exposed to them. In general this time varies from 24 to 72 hours. The objective of this study was to evaluate the in vitro infection times in engorged $\boldsymbol{R}$. microplus females by the EPN Steinernema glaseri CCA strain, by analysis of the ticks' biological parameters.

\section{MATERIAL AND METHODS}

The experiment was performed in the Parasitology Laboratory of the Embrapa Dairy Cattle
Research Center in the municipality of Juiz de Fora, Minas Gerais, Brazil. The infective juveniles (IJs) of Steinernema.glaseri CCA strain (Steiner 1929), isolated from infested eggs of Migdolus fryanus (Coleoptera: Cerambycidae) in the municipality of Araras, São Paulo state, were donated by the São Paulo Biological Institute. The engorged female Rhipicephalus (Boophilus) microplus was obtained from a rural property located in the municipality of Barbacena, Minas Gerais. The nematode colonies were bred and maintained using larvae of Galleria mellonella L. 1758 (KAYA \& STOCK, 1997).

The engorged female ticks' were weighed individually on a precision scale to separate them into homogenous (statistically similar) treatment and control groups. The females exposed to the EPNs were separated in 48 Petri dishes ( $5 \mathrm{~cm}$ in diameter) containing $15 \mathrm{~g}$ of sand previously sifted and sterilized, subdivided into five equal areas by a star-shaped apparatus made of wood. Each engorged female was considered an experimental unit (EU). The ticks were divided into seven groups, each group containing 30 EUs.

To estimate the number of IJs, it was formed a pool of stock solutions, previously stored at $15^{\circ} \mathrm{C} \pm 1^{\circ} \mathrm{C}$ in $25 \mathrm{~mL}$ cell cultivation bottles. After homogenization, it was collected 20 aliquots of $10 \mu$ l of the solution with the IJs and placed them on slides with slip covers for counting under a stereoscopic microscope. The respective concentrations were adjusted to $4 \mathrm{ml}$ of suspension.

The treatment groups were exposed to $4 \mathrm{ml}$ of a suspension of 5.000IJs per Petri dish, or 1.000IJs per tick, following the method of VASCONCELOS et al. (2004). The six treatment groups were exposed to nematodes for the following periods: $2 \mathrm{~h}(\mathrm{G} 1)$, $6 \mathrm{~h}(\mathrm{G} 2)$, 12h (G3), 24h (G4), 48h (G5) and 72h (G6). The control group, $\mathrm{G} 7$, was exposed to $4 \mathrm{ml}$ of distilled water for $72 \mathrm{~h}$.

The labeled Petri dishes were kept in a climate-controlled chamber under ideal conditions for the ticks and the nematodes, at $27 \pm 1^{\circ} \mathrm{C}$ and relative humidity (RH) greater than $80 \%$.

After the exposure times for each treatment described above, the engorged females were removed from the dishes with sand and placed in dishes of equal size without sand, subdivided and identified, and once again placed in the same chamber.

At the end of the oviposition period, the eggs were removed, weighed and transferred to disposable plastic syringes prepared in advance, identified and closed with hydrophilic cotton, and also maintained in a climate controlled chamber at $27 \pm 1^{\circ} \mathrm{C}$ and $\mathrm{RH}>80 \%$. Three days after the end of lay, the 
females were again weighed to obtain the residual weight. The ticks that died before or during lay were weighed three days after death.

The tick mortality was daily recorded by visual observations, such as absence of leg reflexes, changes in coloration and in aspect. The biological parameters analyzed were initial weight of engorged females, preoviposition period, oviposition period, survival period of females, weight of the egg mass, egg production index, nutritional index, larval hatching percentage and efficacy of treatments (DRUMMOND et al., 1973).

It was used analysis of variance (ANOVA) and the Tukey-Kramer test at 5\% significance level to check for the existence of significant differences in the biological parameters of the ticks, according to the action of the treatments. For the treatments where the differences between standard deviations indicate that the sample was not normally distributed, it was substituted by the non-parametric Kruskall-Wallis and Dunn tests for the ANOVA and Tukey-Kramer, respectively.

\section{RESULTS AND DISCUSSION}

Table 1 shows the initial weight of the engorged $\boldsymbol{R}$. microplus females and the survival, prelaying and oviposition periods of the control group and of the treated groups, exposed for different times to the action of $\boldsymbol{S}$. glaseri CCA strain.

The initial weights of the females of the control and treated groups presented statistically similar means, demonstrating the homogeneity of the weights of the females in different groups and guaranteeing that the differences found in the various parameters resulted from the action of the treatments.

The survival period varied from 2 to 15 days in the treated groups. In the control group, the survival period varied from 13 to 17 days. There were no statistical differences among groups 1, 2 and 3, but there was a difference between groups 1 and 2 in comparison with groups 4, 5 and 6, with the survival period being shorter in the groups exposed for more than 24 hours. According to HILL (1998), exposure for a short period reduced the number of IJs that successfully penetrated the females, reducing the lethality of the infection. There were no statistical differences observed among groups 3, 4, 5 and 6, but there was a significant statistical difference between all the treatment groups and the control group regarding survival period.

Statistical difference between the preoviposition period of the control and treated groups was not observed. In all groups it varied from two to four days. A similar finding was reported by VASCONCELOS et al. (2004) for S. glaseri Santa Rosa strain, suggesting there is no interference in the oviposition metabolism in this period. The preoviposition period was similar to that observed by GLÓRIA et al. (1993) in a biological study of the nonparasite phase of $\boldsymbol{R}$. microplus under laboratory conditions, which varied from 1 to 4 days for an acaricide resistant strain.

With respect to the oviposition period, there was no statistical difference among the treated groups, varying from 1 to 12 days, although the oviposition periods were shorter for the ticks exposed to EPNs for longer periods. However, oviposition period was

Table 1 - Average initial weight of the engorged $\boldsymbol{R}$. microplus females and the survival, preoviposition period and oviposition periods of the control group and the groups exposed to the action of the entomopathogenic nematode $\boldsymbol{S}$. glaseri CCA strain. Juiz de Fora, MG. 2006 .

\begin{tabular}{|c|c|c|c|c|c|c|c|c|}
\hline Group & $\mathrm{n}_{\mathrm{iw}}$ & $\begin{array}{l}\text { Initial Weight } \\
\text { (g) }\end{array}$ & $\mathrm{n}_{\mathrm{sp}}$ & $\begin{array}{l}\text { Survival Period } \\
\text { (days) }\end{array}$ & $\mathrm{n}_{\mathrm{pp}}$ & $\begin{array}{c}\text { Preoviposition period } \\
\text { (days) }\end{array}$ & $\mathrm{n}_{\mathrm{op}}$ & $\begin{array}{l}\text { Oviposition period } \\
\text { (days) }\end{array}$ \\
\hline $1(2 \mathrm{~h})$ & 30 & $0.2042^{\mathrm{a}} \pm 0.0068$ & 30 & $7.5^{\mathrm{a}} \pm 0.8980$ & 20 & $2.3^{\mathrm{a}} \pm 0.1051$ & 20 & $7.4^{\mathrm{a}} \pm 1.0010$ \\
\hline $2(6 h)$ & 30 & $0.2009^{\mathrm{a}} \pm 0.0054$ & 30 & $7.8^{\mathrm{a}} \pm 0.7909$ & 22 & $2.3^{\mathrm{a}} \pm 0.1050$ & 22 & $7.8^{\mathrm{a}} \pm 0.6643$ \\
\hline $3(12 h)$ & 30 & $0.2053^{\mathrm{a}} \pm 0.0061$ & 30 & $4.8^{\mathrm{ab}} \pm 0.5775$ & 16 & $2.3^{\mathrm{a}} \pm 0.1250$ & 16 & $4.2^{\mathrm{a}} \pm 0.8342$ \\
\hline $4(24 h)$ & 30 & $0.2005^{\mathrm{a}} \pm 0.0052$ & 30 & $3.3^{b} \pm 0.1986$ & 7 & $2.4^{\mathrm{a}} \pm 0.2020$ & 7 & $2.6^{\mathrm{a}} \pm 0.3689$ \\
\hline $5(48 h)$ & 30 & $0.2013^{\mathrm{a}} \pm 0.0069$ & 30 & $3.6^{\mathrm{b}} \pm 0.2820$ & 10 & $2.4^{\mathrm{a}} \pm 0.1633$ & 10 & $3.1^{\mathrm{a}} \pm 0.4333$ \\
\hline $6(72 \mathrm{~h})$ & 30 & $0.2023^{\mathrm{a}} \pm 0.0042$ & 30 & $3.2^{\mathrm{b}} \pm 0.2095$ & 4 & $2.2^{* *} \pm 0.2500$ & 4 & $3.5^{* *} \pm 0.5000$ \\
\hline $7\left(\mathrm{c}^{* *}\right)$ & 30 & $0.2044^{\mathrm{a}} \pm 0.0064$ & 30 & $14.7^{\mathrm{C}} \pm 0.1815$ & 30 & $2.6^{\mathrm{a}} \pm 0.1148$ & 30 & $12.1^{\mathrm{b}} \pm 0.1871$ \\
\hline
\end{tabular}

$\mathrm{X} \pm \mathrm{SD}=$ mean \pm standard deviation;

Equal overwritten values in the same column do not differ significantly at the $5 \%$ significance level by Tukey-Kramer test or Kruskall-Wallis and Dunn tests for the ANOVA.

* control group; ** $\mathrm{n}$ insufficient

$\mathrm{n}_{\mathrm{iw}}$ : number of ticks evaluated for inicial weight; $\mathrm{n}_{\mathrm{sp}}$ number of ticks evaluated for survival period; $\mathrm{n}_{\mathrm{pp}}$ :number of ticks evaluated for preoviposition period; $\mathrm{n}_{\mathrm{op}}$ : number of ticks evaluated for oviposition period. 
shorter in all the treated groups in relation to the control. This fact can be explained by the mortality caused by the EPNs, so that some ticks did not lay any eggs at all. Group 6 was excluded from the analysis of these parameters due to the reduced number of surviving individuals.

Table 2 presents the average egg mass weights, larval hatching rate, oviposition indices (egg mass weight/engorged female weight) x100 and nutritional indices (egg mass weight/ female weight loss) $\mathrm{x} 100$, of the treated and control groups.

There were statistical differences in the egg mass weights between some groups and between the treated groups and the control group. There was no statistical difference between groups 1 and 2, 1 and 3 and 2 and 3. Starting with group 3 there was no statistical difference in the egg mass of the other treatment groups. This pattern was repeated for the laying and nutritional indices. The parameters of the control group were similar to those obtained in a biological study of $\boldsymbol{R}$. microplus carried out by GLÓRIA et al. (1993), in which the egg mass weight varied from $86.6 \mathrm{mg}$ to $177.7 \mathrm{mg}$ for an acaricide resistant strain. For all the treated groups the number of eggs laid declined as the exposure to the EPNs increased. SAMISH \& GLAZER (1992) reported that after 24 hours of exposure, egg laying was not affected. However, HILL (1998) found that the laying index and larval hatching index declined according to the period the engorged females were exposed, explaining this reduction by the death of the ticks, but without excluding the possibility that the reproductive organs had been affected.

In the present study, although we did not observe a statistical difference in the hatching rate between the treatment and the control groups, there was a tendency for a smaller hatching rate in the treated groups. Hence, there was a definite decline in the fertility index values in the treated groups, revealing the efficacy of the treatments (Figure 1).

The efficacy in treated groups 1 (2h), 2 (6h) and 3 (12h) was below $90 \%$, but above $60 \%$ (respectively $66.0 \%, 78.0 \%$ and $83.7 \%$ ). The other treated groups - G3 (24h), G4 (48h) and G5 (72h) - had satisfactory in vitro results, that is above $90 \%$ of efficacy (respectively 99.9\%, 99.0\% and 97.9\%). VASCONCELOS et al. (2004) described efficacy of treatments above $90 \%$ in engorged $R$. microplus females treated with 1000 EPNs/female, exposed for 72 hours. However, KOCAN et al. (1998a) observed that the exposure of ticks of the Rhipicephalus (Boophilus) annulatus species to EPNs for only one hour resulted in mortality, and this mortality increased linearly to $100 \%$ when the exposure time reached 32 hours. In another study, KOCAN et al. (1998b) exposed partially engorged Amblyomma americanum and Dermacentor variabilis females to the EPN S. riobravus for 8, 24, 48 and 96 hours and found, by microscopic examination, EPNs in the hemocele of those females exposed for 24 hours or more.

\section{CONCLUSION}

In conclusion, it was observed that a period of two hours of in vitro exposure was sufficient for the engorged $\boldsymbol{R}$. (Boophilus) microplus females to be infected by the entomopathogenic nematode $\boldsymbol{S}$. glaseri CCA strain. However, in order to achieve more than $90 \%$ of treatment efficacy, it was necessary an in vitro 24-hour-period of exposure. These results are important to help conducting field studies, which are in course to try to corroborate the laboratory findings.

Table 2 - Egg mass, larval hatching rate, oviposition and nutritional indices of the engorged Rhipicephalus (Boophilus) microplus females of the control group and the groups exposed to the entomopathogenic nematode Steinernema glaseri CCA strain. Juiz de Fora, MG. 2006.

\begin{tabular}{ccccccccc}
\hline Group & $\mathrm{n}_{\mathrm{em}}$ & Egg Mass (g) & $\mathrm{n}_{\mathrm{hr}}$ & Hatching Rate (\%)* & $\mathrm{n}_{\mathrm{oi}}$ & Oviposition Index $^{\mathrm{n}} \mathrm{n}_{\mathrm{ni}}$ & Nutritional Index $^{\mathrm{a}}$ \\
\hline $1(2 \mathrm{~h})$ & 30 & $0.0422^{\mathrm{a}} \pm 0.0078$ & 20 & $48.0^{\mathrm{a}} \pm 8.806$ & 30 & $19.1551^{\mathrm{a}} \pm 3.4064$ & 30 & $35.4961^{\mathrm{a}} \pm 5.1771$ \\
$2(6 \mathrm{~h})$ & 30 & $0.0317^{\mathrm{a}} \pm 0.0061$ & 22 & $27.7^{\mathrm{a}} \pm 8.646$ & 30 & $16.1110^{\mathrm{a}} \pm 3.0753$ & 30 & $39.8052^{\mathrm{a}} \pm 5.1170$ \\
$3(12 \mathrm{~h})$ & 30 & $0.0200^{\mathrm{ab}} \pm 0.0059$ & 16 & $17.5^{\mathrm{a}} \pm 7.665$ & 30 & $10.0101^{\mathrm{ab}} \pm 2.9862$ & 30 & $25.4214^{\mathrm{ab}} \pm 5.0880$ \\
$4(24 \mathrm{~h})$ & 30 & $0.0012^{\mathrm{b}} \pm 0.0005$ & 7 & $1.4^{\mathrm{a}} \pm 1.429$ & 30 & $0.6792^{\mathrm{b}} \pm 0.2911$ & 30 & $6.9891^{\mathrm{b}} \pm 2.8221$ \\
$5(48 \mathrm{~h})$ & 30 & $0.0061^{\mathrm{b}} \pm 0.0028$ & 10 & $1.5^{\mathrm{a}} \pm 1.500$ & 30 & $3.1862^{\mathrm{b}} \pm 1.2731$ & 30 & $7.9760^{\mathrm{b}} \pm 2.8820$ \\
$6(72 \mathrm{~h})$ & 30 & $0.0032^{\mathrm{b}} \pm 0.0018$ & 4 & $5.0^{* * *} \pm 5.000$ & 30 & $1.5801^{\mathrm{b}} \pm 0.8620$ & 30 & $9.9360^{\mathrm{b}} \pm 2.2932$ \\
$7\left(\mathrm{c}^{* *}\right)$ & 30 & $0.1061^{\mathrm{c}} \pm 0.0036$ & 30 & $94.3^{\mathrm{a}} \pm 1.350$ & 30 & $51.9133^{\mathrm{c}} \pm 0.5181$ & 30 & $74.0122^{\mathrm{c}} \pm 0.5554$ \\
\hline
\end{tabular}

$\mathrm{X} \pm \mathrm{SD}=$ mean \pm standard deviation

Equal letters in the same column do not differ significantly at the 5\% significance level by Tukey-Kramer test or Kruskall-Wallis and Dunn tests for the ANOVA.

* data analyzed as ${ }^{2} \sqrt{\arcsin } \mathrm{x} ;{ }^{* *}$ control group; $* * * \mathrm{n}$ insufficient

$\mathrm{n}_{\mathrm{em}}$ : number of ticks evaluated for egg mass; $\mathrm{n}_{\mathrm{hr}}$ : number of ticks evaluated for Hatching rate; number of ticks evaluated for oviposition index; $\mathrm{n}_{\mathrm{ni}}$ : number of ticks evaluated for nutritional index.

Ciência Rural, v.40, n.4, abr, 2010. 


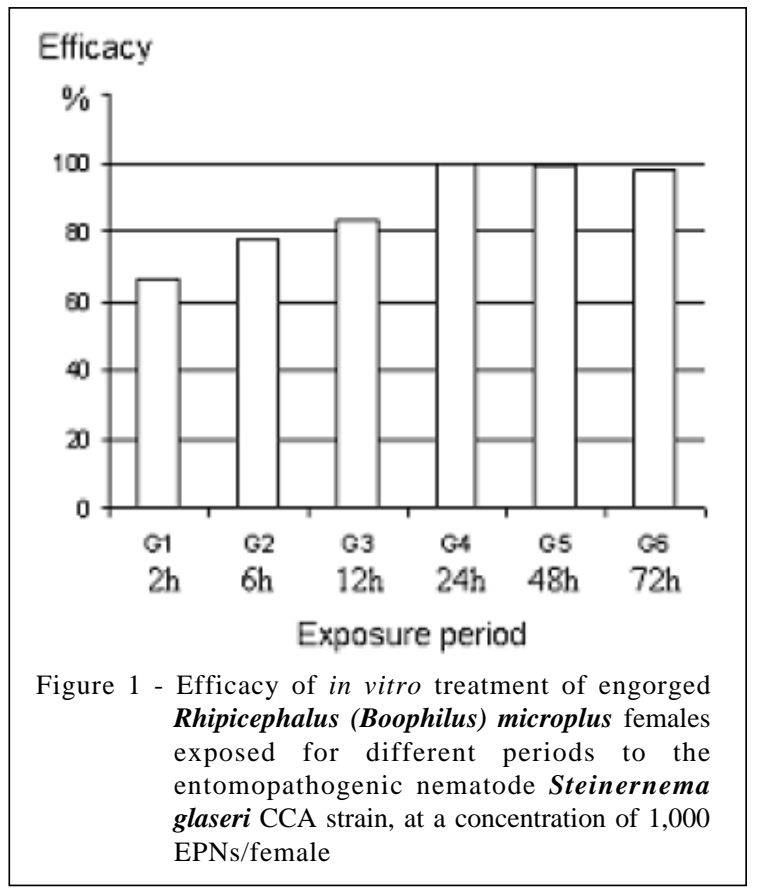

\section{ACKNOWLEDGEMENTS}

The authors thank CAPES (Office for Improvement of University Education), CNPq (National Council for Scientific and Technological Development) and the Embrapa Dairy Cattle Unit for financial support, and also thank Luis Garrigós Leite and Cláudia Dolinsky, for transferring the EPNs. The experiment was done according to the Brazilian laws.

\section{REFERENCES}

DOLINSKI, C. Nematóides como agentes do controle biológico de insetos. In: OLIVEIRA FILHOS, E.C.; MONNERAT, R.G. Fundamentos para regulação de semioquímicos inimigos naturais e agentes microbiológicos de controle de pragas. Brasília: EMBRAPA, 2006. Cap.4, p.73-101.

DRUMMOND, R.O. et al. Boophilus annulatus and Boophilus microplus: laboratory test of insecticides. Journal of Economic Entomology, v.66, p.130-133, 1973. Available from: <http:// www.ncbi.nlm.nih.gov/pubmed/4690254?log\$=activity>. Accessed: 20 nov. 2008.

GLÓRIA, M.A. et al. Influência de diferentes temperaturas sobre a biologia da fase não parasitária de Boophilus microplus (Can.; 1887) (Acari: Ixodidae). Revista Brasileira de Parasitologia Veterinária, v.2, n.2, p.85-91, 1993. Available from: <http://www.cbpv.com.br/rbpv/documentos/221993/ c2285_91.pdf $>$. Accessed: 15 fev. 2009.

GRISI, L. et al. Impacto econômico das principais ectoparasitoses em bovinos no Brasil. A Hora Veterinária, v.21, n.125, p.8-10, 2002.

HILL, D.E. Entomopathogenic nematodes as control agents of developmental stages of the black legged tick, Ixodes scapularis. Journal of Parasitology, v.84, n.6, p.1124-1127, 1998. Available from: <http://www.ncbi.nlm.nih.gov/pubmed/ 9920301>. Accessed: 30 jan. 2009.

KAYA, H.K.; STOCK, P. Techniques in insect nematology. In: LACEY, L.A. Manual of techniques in insect pathology, San Diego: Academic, 1997. p.281-324.

KOCAN, K.M. et al. Interaction of some entomopathogenic nematodes (Steinernematidae) with selected species of ixodid ticks (Acari:Ixodidae). Journal of Medical Entomology, v.35, n.4, p.514-520, 1998a. Available from: <http://cat.inist.fr/ ?aModele=afficheN\&cpsidt=1587797> . Accessed: 11 jul. 2009.

KOCAN, K.M. et al. Entomopathogenic nematodes as a potential biological control method of ticks. Annals of the New York Academy of Sciences, v.849, p.355-364, 1998b. Available from: <http://www.biomedexperts.com/Abstract.bme/ 9668486/Entomopathogenic_nematodes_as_a_pot ential_biological_control_method_for_ticks>. Accessed: 20 nov. 2008 .

KUNZ, E.S.; KEMP, H.D. Insecticides and acaricides: resistance and environmental impact. Revue Scientifique et Technique, v.13, n.4, p.1249-1286, 1994. Available from: <http://www.ncbi.nlm.nih.gov/pubmed/7711312>. Accessed: 29 jun. 2009.

REIS-MENINI, C.M.R. et al. Compatibility between the entomopathogenic nematode Steinernema glaseri (Rhabditida: Steinernematidae) and an acaricide in the control of Rhipicephalus (Boophilus) microplus (Acari: Ixodidae). Parasitology Research, v.103, n.6, p.1391-1396, 2008. Available from: <http://www.springerlink.com/content/ t76w2r1n1m363640/>. Accessed: 13 jun. 2009. doi: 10.1007/ s00436-008-1147-5.

SAMISH, M. et al. Biocontrol of ticks by entomopathogenic nematodes: research update. Annals of the New York Academy of Sciences, v.916, p.589-594, 2000. Available from: <http://www3.interscience.wiley.com/journal/120752301/ abstract?CRETRY=1\&SRETRY=0>. Accessed: 21 nov. 2008. doi: 10.1111/j.1749-6632.2000.tb05341.x.

SAMISH, M.; GLAZER, I. Infectivity of entomopathogenic nematodes (Steinernematidae and Heterorhabditidae) to female ticks of Boophilus annulatus (Acari: Ixodidae). Entomological Society of America, v.29, n.4, p.614-618, 1992. Available from: <http://cat.inist.fr/?aModele=afficheN\&cpsidt=4335822>. Accessed: 23 mai. 2009.

VASCONCELOS, V.O. et al. Steinernema glaseri Santa Rosa strain (Rhabditida: Steinernematidae) and Heterorhabditis bacteriophora CCA strain (Rhabditida: Heterorhabditidae) as biological control agents of Boophilus microplus (Acari: Ixodidae). Parasitology Research, v.94, p.201-206, 2004. Available from: <http://www.springerlink.com/content/ e6pu06nwrkyjbmgc/>. Accessed: 15 mai. 2009. doi: 10.1007/ s00436-004-1178-5.

ZHIOUA, E. et al. Pathogenicity of Steinernema carpocapsae and S. glaseri (Nematoda: Steinernematidae) to Ixodes scapularis (Acari: Ixodidae). Journal of Medical Entomology, v.32, n.6, p.900-905, 1995. Available from: <http:// www.ncbi.nlm.nih.gov/pubmed/8551517>. Accessed: 16 jul. 2009. 